\title{
Orientações a pais e Professores de alunos com altas habilidades
}

Soraia N apoleãoFREITAS ${ }^{1}$

FLEITH, Denise de Souza; ALEN CAR, Eunice M. L. Soriano de. D esenvolvimento de tal entos e al tas habilidades: orientação a pais e professores. Porto Alegre: Artmed, 2007.

O contexto educacional atual, caracterizado pela complexidade dos sistemas de ensino e pela necessidade da busca de al ternativas pedagógicas que respeitem a diversidade, tendo em vista a constituição de organizações de ensino que auxiliem na promoção de uma educação para todos, tem sido eixo articulador dos profissionais da educação que se dedicam à pesquisa na área da Educação Especial.

Nestesentido, pode-se destacar a emergentenecessidadedeampliar a produção científica no quetangeà educação dealunos com al tas habilidades, alunos estes que necessitam de acompanhamento da Educação Especial para seu desenvolvimento e aprendizagem. É partindo desse pressuposto que as autoras Denise de Souza Fleith e Eunice M. L. Soriano de Alencar organizaram a obra "Desenvolvimento detalentos ealtas habilidades: orientação a pais e professores".

Esta obra caracteriza-se por constituir uma col etânea detextos que se debruçam nas questões referentes à definição de concepções sobre as altas habilidades, as características eo processo deidentificação eavaliação destes al unos. Logo, esta pode ser considerada uma referência na área, pois busca articular estes conceitos fundamentais ao papel da família, da escola e da sociedade no processo de desenvolvimento da pessoa com altas habilidades.

Tendo em vista o esclarecimento de conceitos relativos às altas habilidades, as autoras buscaram organizar um referencial quesirva desubsídio à prática pedagógica dos professores, prol ongando estas informações à família eà sociedade, tendo em vista quea educação éum processo quetranscendea instituição escolar equeseconfigura a partir da interação em diferentes contextos.

\footnotetext{
${ }^{1}$ Professora Doutora do Departamento deEducação Especial da Universi dadeFederal deSanta Maria/ UFSM; Coordenadora do Programa de A poio à Pesquisa em Educação Especial PROESP/ CAPES/ UFSM ; Líder do Grupo de Pesquisa CN Pq Educação Especial: interação e inclusão social - soraianf@fatecnet.ufsm.br
} 
O livro é organizado a partir da articulação de três eixos teóricos: o primeiro queaborda as características da pessoa com al tas habilidades; o segundo que se propõe a discorrer acerca do processo de identificação destes alunos e o terceiro eixo sobre informações que pretendem discutir a influência da família e da escola no desenvolvimento de tal entos eal tas habilidades.

A primeira parte do livro promove uma discussão acerca das características das pessoas com altas habilidades, buscando apresentar aos paise professores informações quanto aos aspectos cognitivo, sócio-emocional e moral que contribuam para o processo de identificação, estimulação e desenvolvimento detalentos.

Por sua vez, o segundo eixo teórico se detém na tarefa de clarear conceitos e embasar práticas de identificação e avaliação de alunos com altas habilidades etalentos; enfatiza as áreas de conhecimento relacionadas ao processo criativo e artístico, rompendo, assim, com concepções equivocadas, comumente difundidas, queapresentam queas altas habilidades referem-se somente aos alunos quese destacam nas áreas acadêmicas.

Configurando a terceira parte do livro, são apresentadas produções teóricas que buscam enfatizar a importância da família, da escola e da cultura no desenvol vimento detalentos ealtas habilidades, detendo-se, da mesma forma, na elucidação da relevância dos programas de atendimento para estes alunos, atentando também para a proposição deatendimento para al unos com baixa renda queapresentam potencial superior.

Em síntese, esta obra destaca-se pelo compêndio de informações sobre as altas habilidades, mas, sobretudo, merece atenção pelo fato de colaborar no processo educacional dos alunos com al tas habilidades prolongando o diálogo para além do profissional da educação queatua com estes alunos, abarcando a famíliae a sociedade. Enfim, estelivro infere quea promoção da inclusão deveser pensada a partir de uma concepção processual de educação, que tem como base o engajamento da sociedade nas suas diferentes dimensões. 